\title{
Removal of Hexavalent Chromium from Aqueous Solutions using Some Plants Bark Powder as Adsorbents
}

\author{
Kalandar $\mathbf{A}^{1^{*}}$ and Hiranmai Yadav $\mathbf{R}^{2}$ \\ ${ }^{1}$ School of Medicine, College of Health and Medical Sciences, Post Box No: 235, Haramaya University, \\ Dire Dawa, Ethiopia \\ ${ }^{2}$ School of Natural Resources Management and Environmental Sciences, College of Agriculture and \\ Environmental Sciences, Post Box No.337,Haramaya University, Dire Dawa, Ethiopia
}

\begin{tabular}{|c|c|}
\hline Abstract & Article Infor \\
\hline \multirow{15}{*}{$\begin{array}{l}\text { Heavy metals that have been associated only with chemists have now become a concern of } \\
\text { environmentalist also. They impact the ecosystems when released into water bodies or soil } \\
\text { by various human activities resulting in the environmental pollution. High concentration of Cr } \\
\text { (VI) is harmful to animal and human health. The hexavalent chromium exists in aquatic } \\
\text { media as water soluble complex anions and persist. These are concentrated in industrial } \\
\text { waste water especially from the tannery industries and release of effluents from industries } \\
\text { adversely affects the environment. The removal of heavy metals from aqueous solutions is } \\
\text { carried out by different physical, chemical and biological methods. Now a days, use of } \\
\text { plants waste products such as: barks, manures or lignocellulosic materials, for the removal } \\
\text { of heavy metals from polluted water are becoming of more concern. In the present study, } \\
\text { low-cost and easily available material such as plant barks for the removal of chromium VI } \\
\text { from its aqueous solution was investigated. Bark powders of plants namely, Pongamia } \\
\text { glabra, Tamarindus indicus, Tesphesia populnea, and Mangifera indica obtained from } \\
\text { nearby saw mills, were used as adsorbent for the removal of Cr (VI) from aqueous solutions } \\
\text { in excess of maximum permissible limits. Adsorption for chromium (VI) was found to be } \\
\text { highly dose dependent compared to the other parameters observed with almost } 100 \% \\
\text { efficiency at pH } 2 \text {, contact time of } 2 \mathrm{~h} \text { at room temperature with } 3 \mathrm{~g} \mathrm{I}^{-1} \text { bark dosage. The } \\
\text { adsorption capacities of all the plant barks for chromium (VI) was found to be comparable to } \\
\text { other commercial adsorbents currently employed for the removal of heavy metals from } \\
\text { aqueous wastes. The results have demonstrated the immense potential of plants bark } \\
\text { powder as an alternative adsorbent for removal of Cr(VI) ions from polluted water. } \\
\text { Copyright@2014 STAR Journal. All Rights Reserved. }\end{array}$} & History: \\
\hline & Received : 12-09-2014 \\
\hline & Revised \\
\hline & Accepted : 25-12-2014 \\
\hline & Keywords: \\
\hline & Ads \\
\hline & Chrc \\
\hline & Pon \\
\hline & Tamarindus indicus \\
\hline & Tesphesia populnea \\
\hline & Mangifera indica \\
\hline & ${ }^{\star}$ Corresponding Autho \\
\hline & \\
\hline & E-mail: \\
\hline & \\
\hline
\end{tabular}

\section{INTRODUCTION}

Water of high quality is essential for human existence and agricultural, industrial, domestic and commercial use and all these activities are also responsible for polluting the water. Majority of the industries are water based and a considerable volume of wastewater emanated from these is generally discharged into water sources either untreated or inadequately treated resulting in water pollution (Pandey and Carney, 1998). A study conducted by the Centre for Science and Environment, New Delhi, India, has suggested that over $70 \%$ of available water in India is polluted (C.S.E. Survey, 1982). The contamination of water due to toxic heavy metals through the discharge of industrial wastewater is a global environmental problem (Ajmal et al., 2003).

Currently, environmental pollution has become one of the most important issues faced by human being. It has increased exponentially in the past few years and reached to alarming levels in terms of its toxic effects on living beings. Although pollution due to tanneries in India dates back to 100 years, it received much attention only in the recent past. Toxic heavy metals are considered as one of the strong pollutants that have direct effect on humans and animals. Industrial wastewater containing lead, copper, cadmium, chromium etc. can contaminate groundwater resources and thus lead to serious ground water pollution problems (Nagham, 2010).

Heavy metal contamination of fresh water bodies and aquatic biota are increasingly becoming a matter of serious concern from human health point of view, since many of the aquatic organisms like fish, forms an integral part of human diet. Several studies have been reported on the pernicious effects of chromium in organisms and its carcinogenic compounds (Sala et al., 1995). Chromium has widespread industrial applications. The major industries that contribute to pollution by chromium are electroplating, aluminium conversion, cooling operations, fungicides, metal finishing, plants producing industrial inorganic chemicals, pigments and wood preservatives 


\section{Kalandar and Hiranmai Yadav}

(Trivedi, 1989; Udy, 1956 and Losi et al., 1994). The release of 40-50 ppm level of $\mathrm{Cr}$ has been reported in the effluents of these industries (Zayed and Terry, 2003).

Tannery effluent is one of the most polluting industria wastes generating about $75,000 \mathrm{~m}^{3} /$ day (Sahasranaman and Buljan, 2000). Significant and irreparable damage have already been caused to all forms of life by the tannery particularly in Tamil Nadu, India (Raj et al., 1990). The Central Pollution Control Board, an authority in India to implement the country's environment legislation has placed the tanneries in the list of highly polluting categories of industries under the red category (Bolton and Klein, 1971).

It is estimated that 40,000 tones of basic chromium sulphate (BCS) are used in Indian tanneries per year and since only 50 to $70 \%$ of BCS is taken up by leather, the balance 15,000 tones of it is discharged as waste in the effluent (Rajamani and Raghavan, 1995). These effluents have high concentrations of heavy metals (Shanker et al., 2005).Chromium (VI) has been reported highly toxic to most of the organisms (Merroun et al., 1998; Wan Ngah and Hanafiah, 2008). Carcinogenicity of Chromium in experimental animals is well documented by Cohen and Costa (1997).

Exposure of cells of organisms to chromate results in different types of DNA damage, including DNA interstrand cross links, DNA protein cross links, oxidative base damage and DNA strand breaks (Cupo and Welterhann, 1985). Exposure to chromium (VI) results in complications during pregnancy and childbirth in the form of toxicosis and hemorrhages in women employees at a dichromate manufacturing factory (Shmitova, 1989). Nephrotoxicity, respiratory carcinoma, hepatotoxicity, cardiotoxicity and genotoxicity are reported in workers engaged in chromium based industries (Friberg et al., 1986 and WHO, 1988).

Chromium also causes renal failure leading to the loss of osmoregulatory ability and respiration in fish (Artillo and Melodio, 1988). Even short time chromium (VI) exposure severely damages kidney, intestine and lungs (Rahul Kundu et al., 2002). Chromium in polluted water causes asthma, ulcers, lung cancer, skin lesions, dermatitis, perforation of nasal septum (Veenamani et al., 2005). Chromium (III) causes DNA damage and inhibits topoisomerase DNA relaxing ability probably by preventing the formation of covalent link between enzyme and double helix (Andreja, 2002).

Removal of heavy metals from aqueous solutions are carried out by a number of physical and chemical methods like electro-chemical precipitation, ultra filtration, ion exchange and reverse osmosis. But these methods are economically not feasible and have their technical limitations as well. Therefore, biological methods are used to remediate the heavy metals. These involve the use of plant products and microorganisms for the removal of heavy metals from aqueous solutions (Nomanbhai and Palanisamy, 2005). In the recent years, the need for safe and economical methods for the elimination of heavy metals from contaminated waters has necessitated research interest towards the production of low cost alternatives to commercially available materials such as activated carbon. Therefore, there is an urgent need that possible sources of agro-based inexpensive adsorbents may be explored for the removal of heavy metals.
Sci. Technol. Arts Res. J., Oct-Dec 2014, 3(4): 99-106

Krishnani et al. (2004) used biosorbents from rice husk, paddy straw, and bagasse for the removal of $\mathrm{Cr}(\mathrm{VI})$ at $\mathrm{pH}$ 2. They reported that $\mathrm{Cr}(\mathrm{VI})$ exist as oxo-anions which cannot bind to negatively charged carboxylic ligands at higher $\mathrm{pH}$ (Parimala et al., 2004; Krishnani et al 2004). Dubey and Krishna (2007) reported that the maximum adsorption capacity of most investigated biosorbents were in the range of $1.6-13.4 \mathrm{mg} / \mathrm{g}$ for unmodified bio-sorbents.

Shrichand et al. (1994) has studied the effect of bagasse and coconut jute for the removal of $\mathrm{Cr}(\mathrm{VI})$. Logeswari et al. (2013) have reported that the utilization of eucalyptus bark is effective for the removal of chromium from synthetic tannery effluent. Utilization of Eucalyptus bark as an efficient chromium removal material was reported by Xavier et al. (2013). The efficiency of Eucalyptus tereticornis barks was also reported by Sharma and Goyal (2011). Rakesh Kumar et al. (2012) reported the adsorption of chromium (VI) on the waste tree bark. Shetie and Wassie (2013) used moringa seed powder for the removal of chromium from tannery wastes.

Mamatha et al. (2012) have studied the adsorption potential of Pongamia pinnata tree bark for the removal of ferrous and ferric ions from aqueous and industrial effluent. Pathania et al. (2009) has observed the interaction of copper ion on bark material follow a cation exchange mechanism which is supported by elution process in which recovery of about $90 \%$ of copper took place. Harman et al. (2007) studied the removal of heavy metals from polluted waters using lignocellulosic agricultural waste products.

In the present study, bark powder of plants: Pongamia glabra, Tamarindus indicus, Tesphesia populnea, and Mangifera indica have been used as adsorbent for the removal of $\mathrm{Cr}(\mathrm{VI})$ from aqueous solutions. Effects of metal ions initial concentration; contact time and adsorbent dose have been investigated. Maximum metal sorption capacity of each studied adsorbent has also been determined.

\section{MATERIALS AND METHODS}

\section{Preparation of $\mathrm{Cr}(\mathrm{VI})$ Solutions}

Chromium stock solutions were prepared by taking $3.734 \mathrm{~g} \mathrm{~K}_{2} \mathrm{CrO}_{4} .6 \mathrm{H}_{2} \mathrm{O}$ in a $1000 \mathrm{ml}$ volumetric flasks and made up to the mark using deionized water. All the required working solutions were prepared by diluting the stock solutions with deionised water. Analysis of standards and simulated samples was performed using an atomic absorption spectrometer.

\section{Preparation of Plant Bark Powder}

Bark of natural plants Tamarindus indicus (TIBM), Pongamia glabra(PGBM), Tesphesia populnea (TPBM) and Mangifera indica(MIBM) were collected from suburb of Chennai, Tamil Nadu, India. The bark was washed with deionized water, dried at room temperature for 3 days and ground to get the particle size of 200 - 250 mesh and stored in moisture-free atmosphere before further use.

\section{Chromium (VI) lons Adsorption Study}

In a typical run, $100 \mathrm{ml}$ of $\mathrm{Cr}(\mathrm{VI})$ ions solution of given concentration was mixed with a known catalyst load in an Erlenmeyer flask at $25{ }^{0} \mathrm{C}$ maintained using a water thermostat. The $\mathrm{pH}$ of the solution was adjusted at 2 using $1 \mathrm{M} \mathrm{HNO}_{3}$ and the reaction mixture was magnetically 


\section{Kalandar and Hiranmai Yadav}

stirred at $100 \mathrm{rpm}$. Five $\mathrm{ml}$ of the reaction mixture was collected at 1 and 2 hrs, respectively, and filtered. The concentration of $\mathrm{Cr}(\mathrm{VI})$ in the clear filtrate was determined using an Atomic Absorption Spectrophotometer.

Amount of metal ions adsorbed, 'Q' (in mg per gram adsorbent) was obtained by using the equation-

$$
Q=\left(C_{i}-C_{e}\right)(V / m)
$$

Where $C_{i}$ and $C_{e}$ are the initial and equilibrium concentrations, respectively, of metal ions (in $\mathrm{mg} / \mathrm{L}$ ), ' $\mathrm{m}$ ' is the dry mass of bark material in grams and ' $\mathrm{V}$ ' is the volume of solution in liters.

\section{RESULTS AND DISCUSSION}

Percentage removal of $\mathrm{Cr}(\mathrm{VI})$ using bark powders of different plants at varying adsorbent load, $\mathrm{Cr}$ (VI) initial concentration and contact time are recorded in table 1 and figures 1 to 10 .
Sci. Technol. Arts Res. J., Oct-Dec 2014, 3(4): 99-106

\section{Effects of $\mathrm{Cr}(\mathrm{VI})$ concentration}

At the given adsorbent dose and the contact time, irrespective of the plant bark powder used as adsorbent, percent removal of $\mathrm{Cr}(\mathrm{VI})$ ions decreases with the increase of their initial concentration. It may be due to availability of lesser number of adsorbent active sites per $\mathrm{Cr}(\mathrm{VI})$ ion at higher concentrations. Also, at higher initial concentrations of $\mathrm{Cr}(\mathrm{VI})$ ions, a fewer binding sites on the adsorbent surface are left unoccupied for the adsorption of fresh $\mathrm{Cr}(\mathrm{VI})$ ions. Similar observations have been made by Yohannes and Devi Prasad (2014) during biosorption of hexavalent chromium on Cassia spectabilis bark. Our results are in consistence with those reported by Singh et al. (1994). Further, Modak and Natrajan(1995) have also observed an increase in the metal adsorption when the initial concentration of the metal ion was taken as low. Order of $\mathrm{Cr}(\mathrm{VI})$ ions removal efficiency of studied plant barks as adsorbent, was found to be: Tamarindus indicus > Tesphesia populnea > Pongamia glabra > Mangifera indica.

Table 1: Percentage removal of $\mathrm{Cr}(\mathrm{VI})$ using bark powder of different plants at varying adsorbent load, $\mathrm{Cr}(\mathrm{VI})$ initial concentration and contact time

\begin{tabular}{|c|c|c|c|c|}
\hline \multirow{2}{*}{$\begin{array}{c}\text { Initial concentration } \\
\text { Of } \mathrm{Cr}(\mathrm{VI})\left(\mathrm{mgL}^{-1}\right)\end{array}$} & \multicolumn{2}{|c|}{$1 \mathrm{hr}$} & \multicolumn{2}{|c|}{$2 \mathrm{hr}$} \\
\hline & $1 \mathrm{~g} \mathrm{l}^{-1}$ bark & $3 \mathrm{~g} \mathrm{l}^{-1}$ bark & $1 \mathrm{~g} \mathrm{l}^{-1}$ bark & $3 \mathrm{~g} \mathrm{l}^{-1}$ bark \\
\hline PGBM $^{*}$ & \multicolumn{4}{|c|}{$\%$ of metal removal } \\
\hline 2.024 & 60.0 & 87.5 & 70.0 & 90.0 \\
\hline 6.120 & 50.0 & 65.0 & 58.3 & 75.0 \\
\hline 10.081 & 35.0 & 50.0 & 45.0 & 60.0 \\
\hline \multicolumn{5}{|l|}{ TIBM } \\
\hline 2.024 & 70.0 & 100.0 & 80.0 & 100.0 \\
\hline 6.120 & 63.3 & 75.0 & 71.6 & 85.0 \\
\hline 10.081 & 50.0 & 61.0 & 65.0 & 78.0 \\
\hline \multicolumn{5}{|l|}{ TPBM } \\
\hline 2.024 & 65.0 & 90.0 & 75.0 & 91.0 \\
\hline 6.120 & 51.6 & 71.6 & 63.3 & 81.6 \\
\hline 10.081 & 40.0 & 58.0 & 50.0 & 72.0 \\
\hline \multicolumn{5}{|l|}{ AIBM } \\
\hline 2.024 & 50.0 & 75.0 & 55.0 & 80.0 \\
\hline 6.120 & 45.0 & 58.3 & 48.3 & 63.0 \\
\hline 10.081 & 30.0 & 42.0 & 38.0 & 55.0 \\
\hline
\end{tabular}

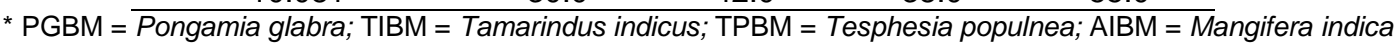

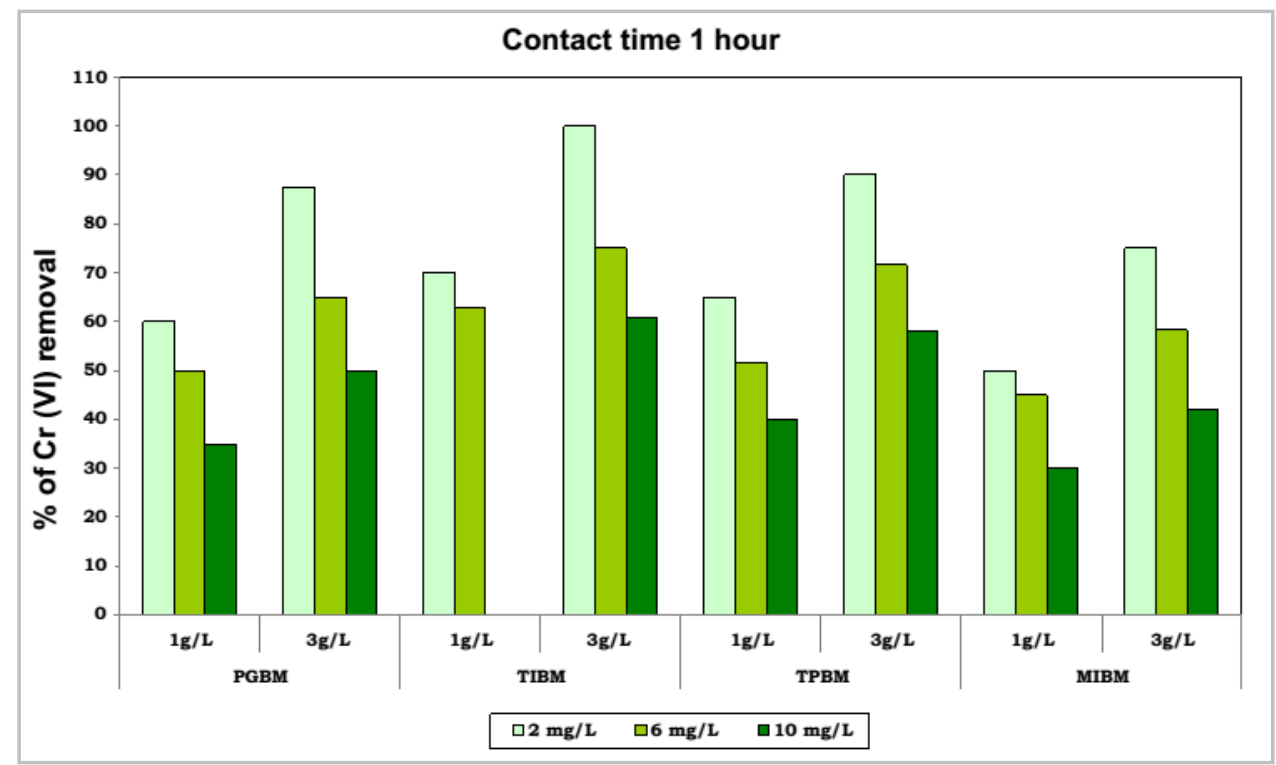




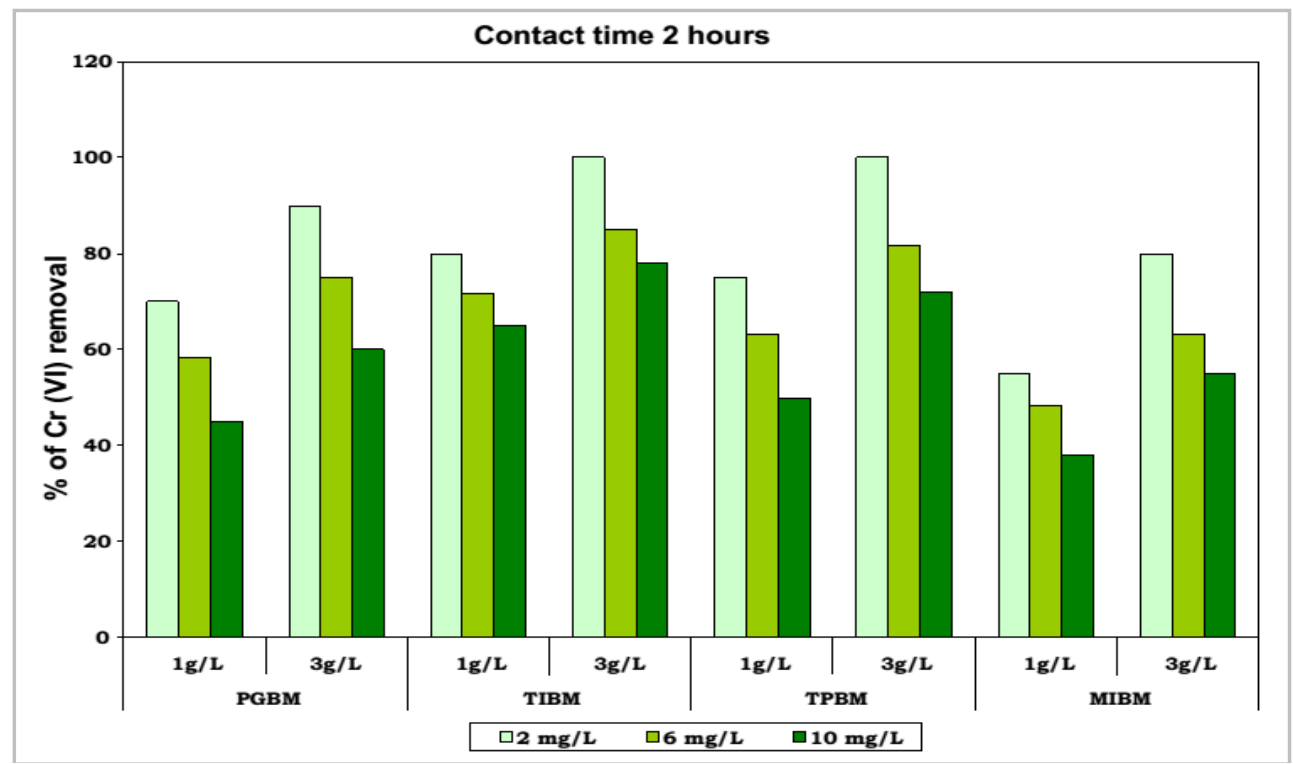

Figure 1 and 2: Effect of Initial metal concentration on the removal of $\mathrm{Cr}(\mathrm{VI})$ using PGBM, TIBM, TPBM and MIBM
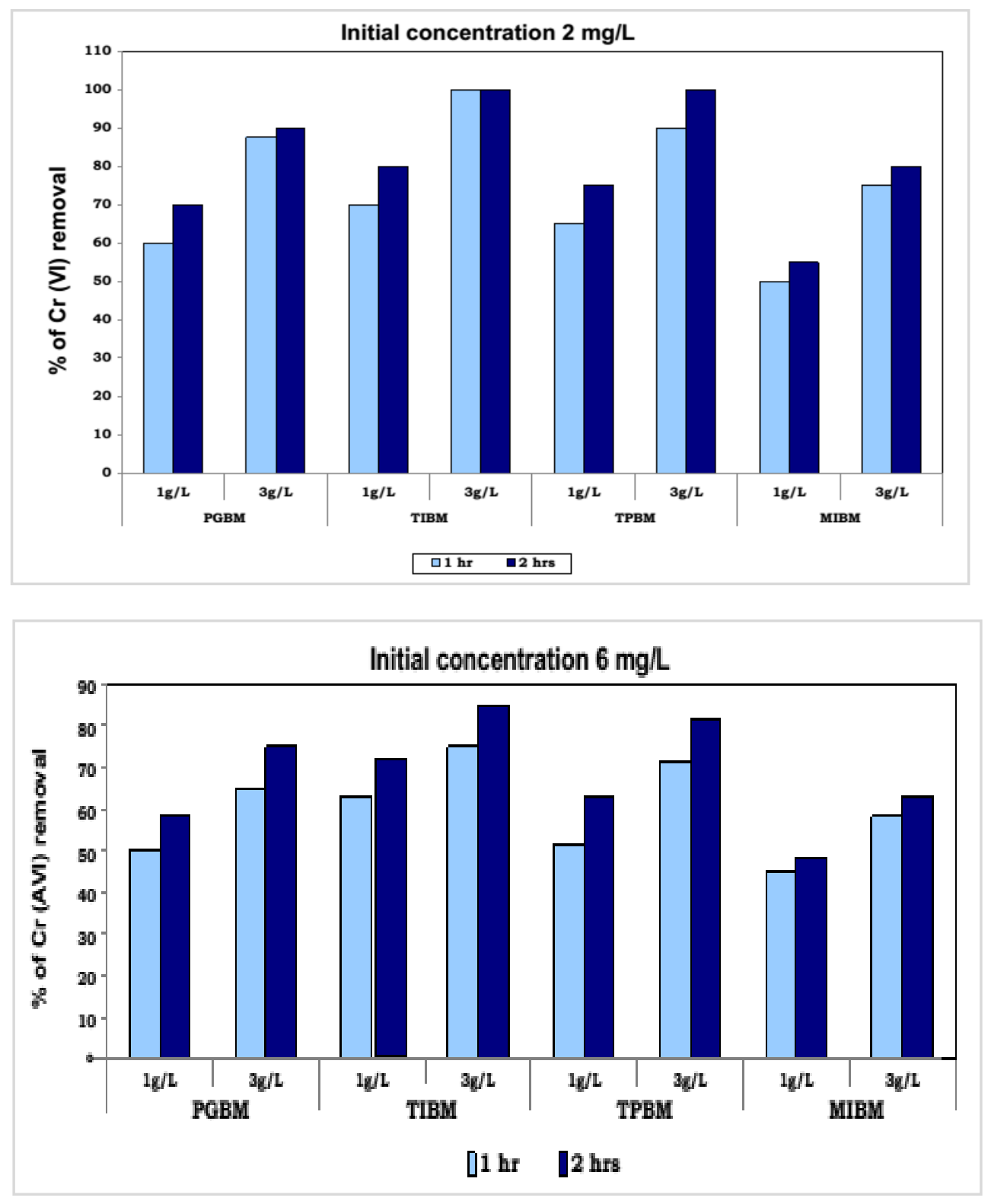


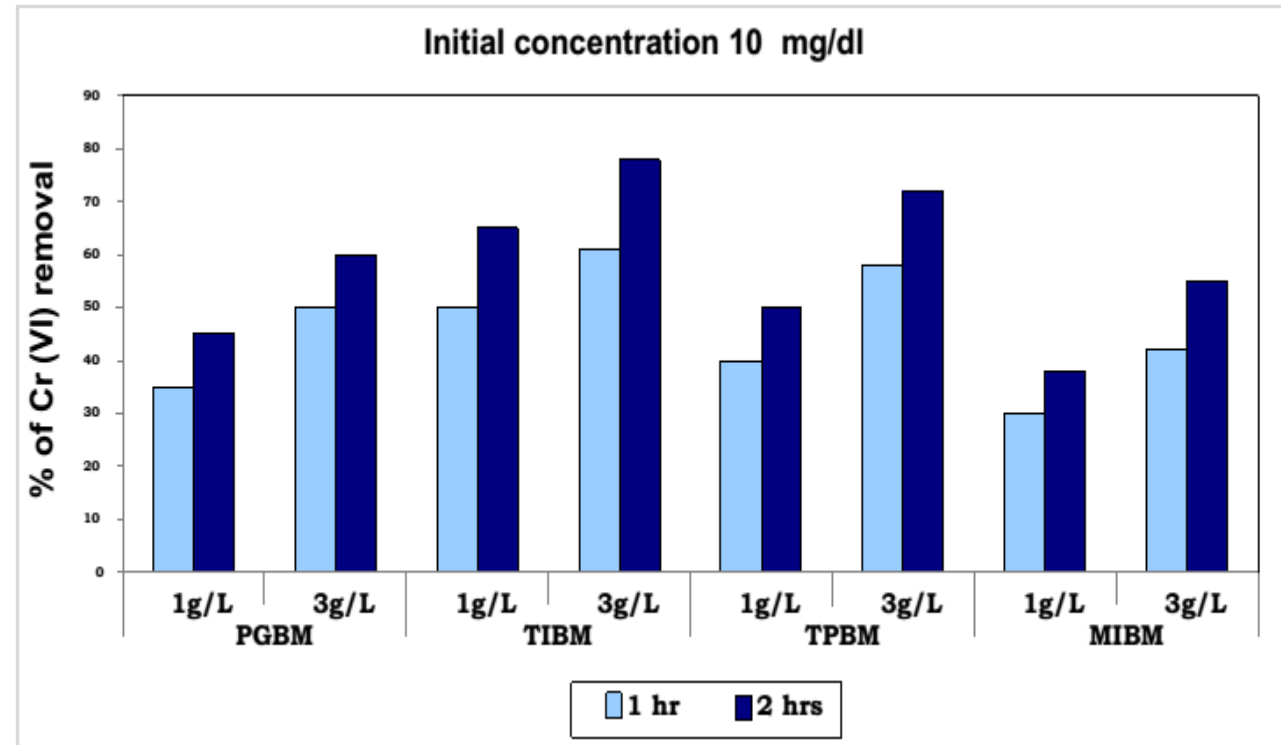

Figure 3, 4 and 5: Effect of contact time on the removal of $\mathrm{Cr}(\mathrm{VI})$ using PGBM, TIBM, TPBM and MIBM
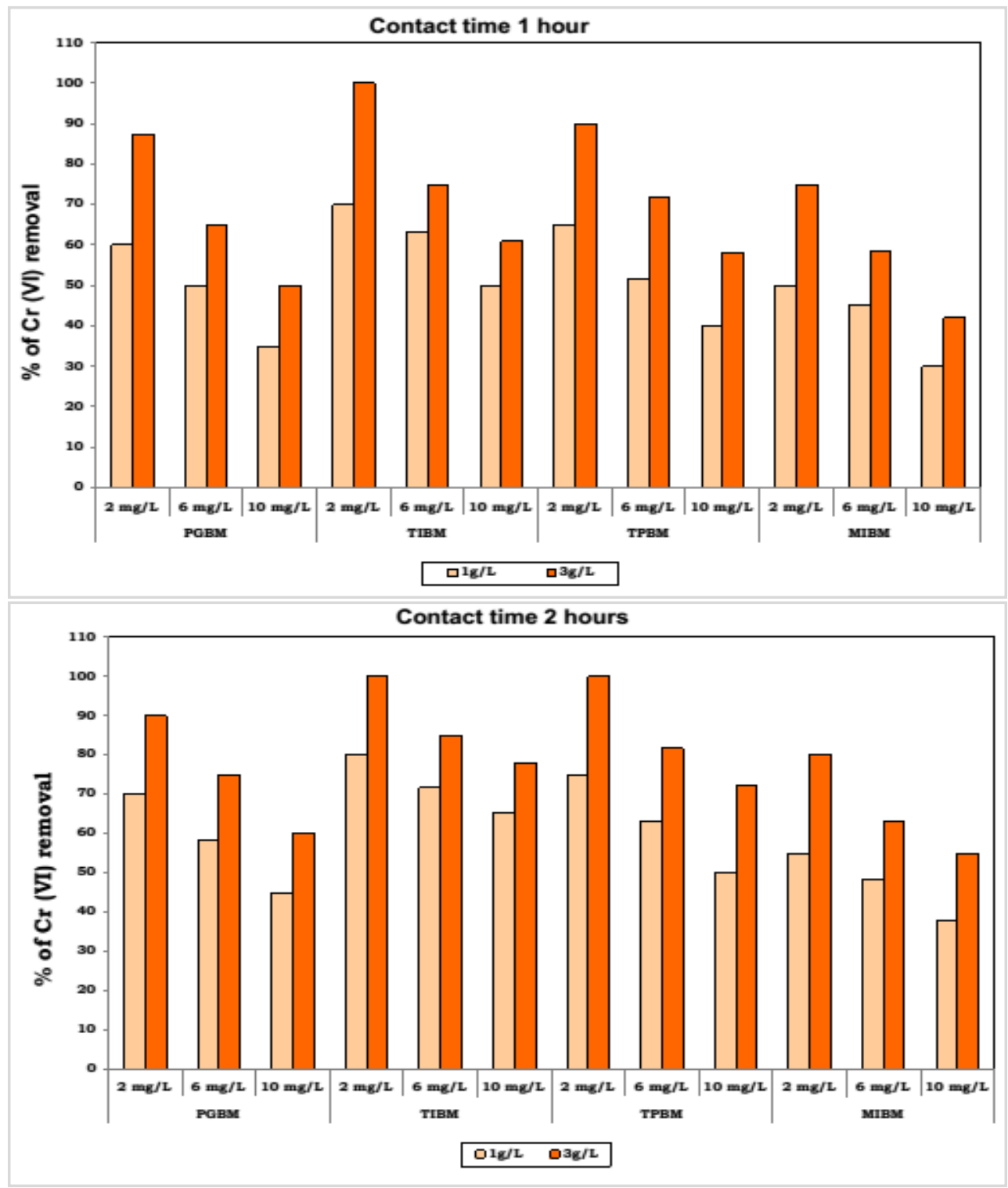

Figure 6 and 7: Effect of bark dose on the removal of $\mathrm{Cr}$ (VI) using PGBM, TIBM, TPBM and MIBM 

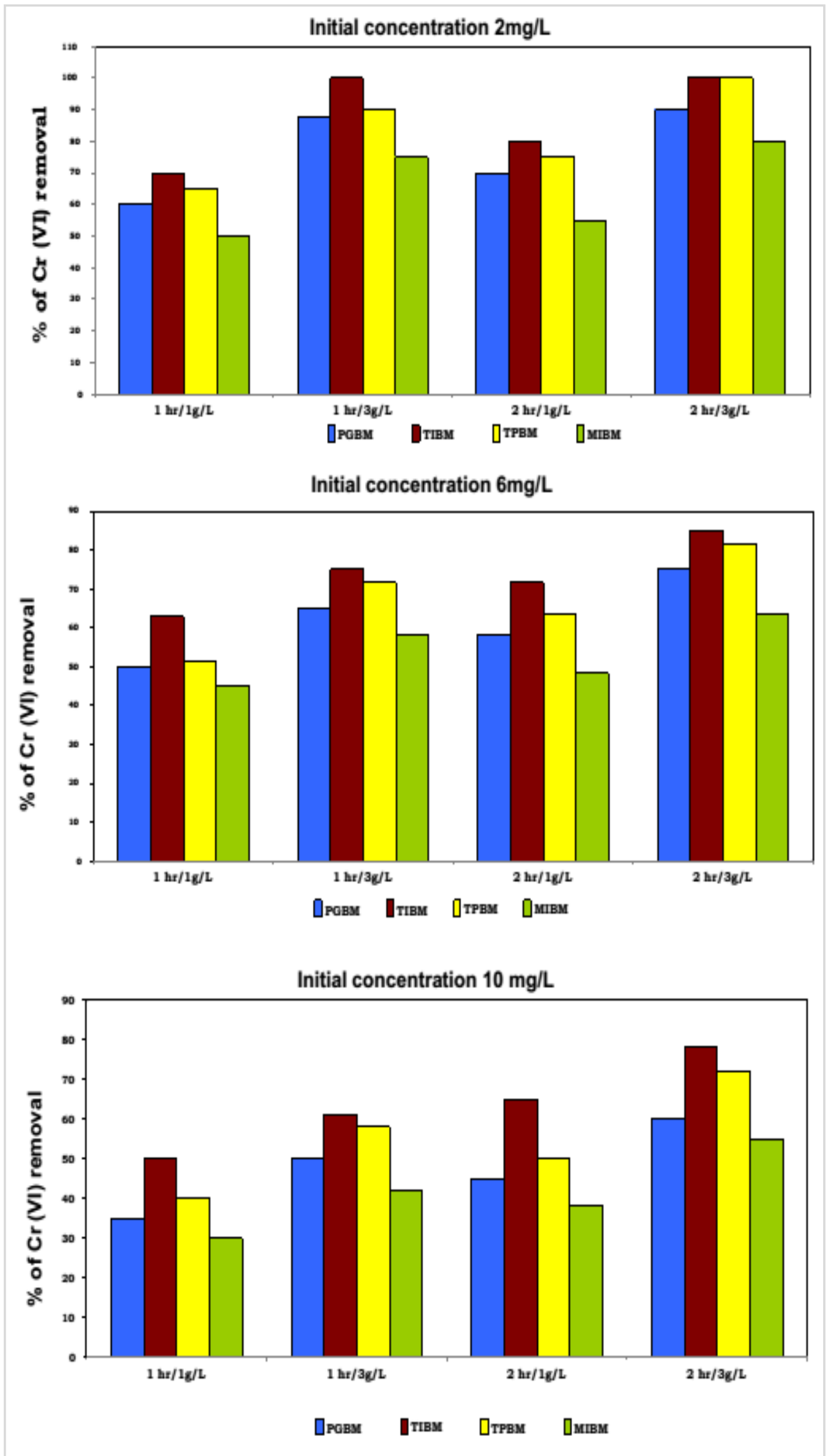

Figures 8, 9 and 10: Efficacy of the PGBM, TIBM, TPBM and MIBM plant barks on the removal of $\mathrm{Cr}$ (VI) 


\section{Kalandar and Hiranmai Yadav}

\section{Effect of Adsorbent Dose}

The observed data presented in table 1 revealed that for each studied $\mathrm{Cr}(\mathrm{VI})$ ion initial concentration, removal of metal ions increased on raising the adsorbent dose from 1 to $3 \mathrm{~g} / \mathrm{L}$. It is obvious since at higher adsorbent dose the number of available adsorbent's active sites per $\mathrm{Cr}(\mathrm{VI})$ ion increases. Our results are in agreement with studies by Malkoc et al. (2006). They observed an increase in $\mathrm{Cr}(\mathrm{VI})$ uptake from 51.7 to $98.6 \%$ as the dose concentration was increased from $5 \mathrm{mg} / \mathrm{L}$ to $15 \mathrm{mg} / \mathrm{L}$. Findings in this study are also similar to those reported in literature for adsorption on coconut jude, bagasse (Shrichand et al., 1994), Garcinia cambogia (Chandrasekar et al., 2002) and rice straw (Samanta et al., 2000). Using $1 \mathrm{~g} / \mathrm{l}$ adsorbent powder from Tamarindus indicus bark, it was possible to completely remove $\mathrm{Cr}(\mathrm{VI})$ ions from their $2.024 \mathrm{mg} / \mathrm{L}$ solution.

\section{Effect of Contact Time on $\mathrm{Cr}$ (VI) Adsorption}

For each studied $\mathrm{Cr}(\mathrm{VI})$ initial concentration and the adsorbent dose, the percent removal of metal ions increases on increasing the contact time for the adsorbate and the adsorbent. However, with the limited data, it is not possible to know the exact time required to establish sorption-desorption equilibrium for the studied sorbatesorbent systems. Present results are corroborated with the work reported in literature (Samanta et al. 2000; Saravanane et al., 2002). Kalandar and Hiranmai (2014) have also reported the efficiency of plant barks for removal of cadmium from aqueous solutions.

\section{CONCLUSIONS}

Barks of Pongamia glabra, Tamarindus indicus, Tesphesia populnea, and Mangifera indica have been used as adsorbents for the removal of $\mathrm{Cr}$ (VI) from aqueous solution using batch operation. The extent of removal of $\mathrm{Cr}(\mathrm{VI})$ from aqueous solutions strongly depends on $\mathrm{Cr}(\mathrm{VI})$ ions initial concentration, contact time and adsorbent dose. It is observed that the studied, locally available, low cost plant barks can be used as alternative adsorbents for $\mathrm{Cr}(\mathrm{VI})$ remediation form polluted water.

\section{ACKNOWLEDGEMENT}

The authors are grateful to the staffs and facilities provided by the Haramaya University, Ethiopia and the post graduate and research department of chemistry, Presidency College, Chennai, Tamilnadu, India.

\section{REFERENCES}

Ajmal, M., Rao, R.A.K.., Anwar, S., Ahmad, J. and Ahmad, R. (2003). Adsorption studies in rice husk removal and recovery of Cadmium (II) from wastewater. Bioresource Technology 86: 147-149.

Andreja. (2002). Genotoxiciy of trivalent Chromium in bacterial cells, possible effect on DNA Topology. Chemical Research in Toxicology 15: 943-949.

Artillo, A. and Melodio, F. (1988). Effects of hexavalent Chromium on the front mitochondria. Toxicology Letters (Amst) 44: 71-76.

Botlon, R.L. and Klein,L. (1971). Sewage treatment- basic principles and trends. Ann Arbor publication, Michigan.

C.S.E Survey. (1982). Survey of Indian Environment Centre for Science and Environment. New Delhi, India.
Sci. Technol. Arts Res. J., Oct-Dec 2014, 3(4): 99-106

Chandrasekar, K., Chary, N.S. and Kamala, C.T. (2002). Application of Garcinia combogia -A plant biomass for chromium removal and speciation studies. International Journal of Environmental Studies 5: 1097-7104.

Cohen, M.D. and Costa, M. (1997). Chromium compounds. In: W.N. Rom (ed.), Environmental and occupational medicine, $2^{\text {nd }}$ ed. Boston: Little, Brown.

Cupo, D.Y. and Welterhann, K.E. (1985). Modification and chromium (VI) induced DNA damage by glutathione and cytochrome $\mathrm{p}-450$ in chicken embryo hepatocytes. Proceedings of the National Academy of Sciences, USA 82: 6755-6759.

Dubey, S. P. and Krishna, G. (2007). Adsorption of chromium (VI) on low cost adsorbents derived from agricultural waste material. Journal of Hazardous materials 145: 465470.

Friberg, L, Nordberg, G.F. and Vouk, V.B. (1986). Handbook of Toxicology of Metals; Vol. 2, $2^{\text {nd }}$ Ed. Elsevier, Amsterdam.

Harman, G ., Patrick, R. and Spittler, T. (2007). Removal of heavy metals from polluted waters using lignocellulosic agricultural waste products. Industrial Biotechnology Winter 366-374.

Kalandar, A. and Hiranmai Yadav, R. (2014). Removal of Toxic Cadmium from Aqueous Solution using natural adsorbents - an eco-friendly method. Research Journal of Environmental Toxicology 8: 1-7.

Krishnani, K.K., Parimala, V. and Meng, X. (2004). Detoxification of hexavalent chromium from coastal water using lignocellulosic waste. Water SA 30: 541-545.

Logeswari, A., Mano, S., Merly Xavier, A., Thirumarimurugan, M. and Kannadasan, T. (2013). Removal of chromium from synthetic tannery effluent by using bioadsorbents. IOSR Journal of Environmental Science, Toxicology and food technology 3: 72-76.

Losi, M.E., Amehein, C. and Frankkenberger, W.T (1994). Environmental Biochemistry of Chromium. Review on Environmental Contamination andToxicology 136:91-121.

Malkoc, E., Nuhoglu, Y. and Dundar, M. (2006). Adsorption of chromium (VI) on pomace-An olive industry waste: Batch and column studies. Journal of Hazardous Materials 138: 142-151.

Mamatha, M., Aravinda, H.B., Puttaiah, E.T. and Manjappa, S. (2012). Adsorption of ferrous and ferric ions in aqueous and industrial effluent onto Pongamia pinnata tree bark. International Journal of Chemical, Material Science and Engineering 6: 9-17.

Merroun, M.L., Omar, N.B., González-Muňoz, M.T. and Arias, J.M. (1998). Myxococcus xanthus biomass as adsorbent for lead. Journal of Applied Microbiology 84: 63-67.

Modak, J.M. and Natarajan, K.A. (1995). Biosorption of metal using nonliving biomass. A Review in Metal Process 12: 189-196.

Nagham A.A. (2010). The use of local sawdust as an adsorbent for the removal of Copper lon from wastewater using fixed bed. Adsorption Journal 28: 859-860.

Nomanbhay, S.M. and Palanisamy, K. (2005). Removal of heavy metal from industrial waste water using chitosan coated oil palm shell charcoal. Electronic Journal of Biotechnology 8:43-53 


\section{Kalandar and Hiranmai Yadav}

Pandey, G.N. and Carney, G.C. (1998).Environmental Engineering. Tata McGraw Hill Publishing Company Limited, New Delhi.

Parimala V., Krishnani K.K., Gupta B.P. and Jayanthi, M. (2004). Phytoremediation of chromium from seawater using five different products from coconut husk. Bulletin of. Environmental Contamination and Toxicology 73: 3137.

Pathania,D., Rana, R.K. and Singh,D. (2009). Chemically modified bark for $\mathrm{Cu}$ (II) sorption from aqueous solution. International Journal of Theoretical and Applied Sciences $1: 25-31$.

Rahul Kundu., Dolly Patel., Sanjay Dave., Nilesh Patel and Sambath Kumar, K. (2002). Influence of short term Chromium (VI) Toxicity and subsequent withdrawal of toxic stress to some membrane bound enzymes in mice, Advances in Pharmacology and Toxicology 3: 47-62.

Raj, E.M., Sankaran, D.P., Sreenath, S.K., Kumaran, S. and Mohan, M. (1990). Studies on treated effluent characteristics of a few tanneries at Chrompet. Madras. Indian Journal of Environmental Protection 6: 252 - 254.

Rajamani S. and Raghavan K.V. (1995). Mitigation of Environmental Impact of Tannery Effluents. Proceedings of $4^{\text {th }}$ National Symposium on Environment. Pp.7-14.

Rakesh Kumar., Sangeetha Obrai and Aparna Sharma (2012). Biosorption of heavy metal ions by using modified waste tree bark material. International Journal of Environmental Sciences 3: 720-726.

Sahasranaman A. and Buljan J. (2000). Environment Management in Indian Tanneries. In: $34^{\text {th }}$ LERIQ: 27- 30.

Sala, L.F., Rizzoto, A., Frascavoli, M.I. Palopoli, C.M. and Singorella, S.R. (1995). Contamination of ambient porel metal transition of chromium. Quimica Nova 8: 168-474.

Samanta J.K., Basu and Kundu, G. (2000). Removal of hexavalent chromium from aqueous solution by using Low cost adsorbent. Indian Journal of Environmental Protection 20: 754-760.

Saravanane R., Sundararajan T. and Siva Murthy Reddy, S. (2002). Efficiency of chemicals modified low cost adsorbents for the removal of heavy metals from wastewater: A comparative study. Indian Journal of Environmental Health 44: 78-87.

Shanker, A.K., Ravichandran, V., Pathmanabhan, G. (2005). Phytoaccumulation of chromium by some multipurposetree seedlings, Agroforestry Systems 64: 83-87.
Sci. Technol. Arts Res. J., Oct-Dec 2014, 3(4): 99-106

Sharma, I. and Goyal, D. (2011). Chromium removal from industrial effluent by Eucalyptus tereticornis bark. Asian Journal of Experimental Sciences 25: 29-35.

Shetie, G. and Wassie M. (2013). Tannery waste water treatment using Moringa stenopetala seed powder extract. Wyno Academic Journal of Physical Science 1: 18.

Shmitova, L.A . (1989). Content of hexavalent chromium in the biological substract of pregnant women and women in the immediate post natal period engaged in the manufacture of chromium compounds. Gigiena Truda I Professionalnye Zabolevaniia 2:33 (Russian).

Shrichand, Agarwal V.A. and Pavankumar. (1994).Removal of hexavalent Chromium from waste water by adsorption. Indian Journal of Environmental Health 36: 151-158.

Singh D.K., Saksena D.W. and Tiwari D.P. (1994). Removal of Chromium (VI) from aqueous solutions, Indian Journal of Environmental Health 36: 272-277.

Trivedi, R.K. (1989). Pollution management in industries, Ed. II, Environmental publications, KARAD, pp180.

Udy, M.J. (1956). Chromium. Rein hold publishing corporation, New York.

Veenamani., Harjit Kaur and Madhu Mohini. (2005). Toxic metals and Environmental pollution. Journal of Industrial Pollution Control 21: 101-107.

Wan Ngah, W.S. and Hanafiah, M.A.K.M. (2008). Removal of heavy metal ions from waste water by chemically modified plant wastes as adsorbents: A review. Bioresource Technology 99: 3935-3948.

WHO (1988). Environmental Health Criteria.61 Chromium, General; International program on chemical safety.

Xavier, M. A.,Logeswari, A. and Mano,S .(2013). Removal of chromium from real tannery effluent by using bioadsorbents. International Journal of Engineering and Science, 2:35-40.

Yohannes, T. and Devi Prasad A.G. (2014). Biosorption of Hexavalent Chromium Using Bark of Cassia spectabilis. Science, Technology and Arts Research Journal 3: 83-87.

Zayed, A.M. and Terry, N. (2003). Chromium in the environment: factors affecting biological remediation. Plant and Soil 249: 139-156 